\title{
INSIDE THE INDONESIAN MIGRATION: A HISTORICAL PERSPECTIVE
}

\author{
Hilda Masniarita Pohan \\ Yodi Izharivan
}

\author{
Center for Economic Studies - Parahyangan Catholic University \\ Email: mpohan@unpar.ac.id
}

Submitted: Oct 3, 2016; Reviewed: Oct 10, 2016; Accepted: Dec 21, 2016

\begin{abstract}
Abstrak: Migrasi telah lama menjadi bagian hidup masyarakat Indonesia. Dalam berbagai kesempatan, migrasi didorong oleh berbagai faktor selain alasan klasik berupa perbaikan kondisi sosio-ekonomi. Alasan-alasan lain tersebut di antaranya: berkumpul dengan keluarga dan faktor keamanan. Melalui kajian pustaka, artikel ini bertujuan untuk memaparkan aspek historis berbagai faktor yang mendorong terjadinya migrasi di Indonesia. Artikel ini diharapkan dapat menjadi bagian integral dari berbagai penelitian lanjutan dalam upaya menjelaskan dinamika migrasi di Indonesia. Perubahan-perubahan tatanan politik yang mendasar di Indonesia memengaruhi aktivitas ekonomi; termasuk migrasi. Penelitian kami menunjukkan bahwa migrasi hampir selalu didorong oleh motif ekonomi walaupun dimanifestasikan dalam bentuk yang berbeda-beda.
\end{abstract}

Keywords: Indonesia; Kebijakan Pemerintah; Migrasi; Pertimbangan Ekonomi

\section{INTRODUCTION}

Migration is a global phenomenon. According to The World Bank, by 2010 there are more than 200 million people in the world who are living outside of their place of origin. For example, there are approximately 42.8 million migrants living in the US, 10.7 million in Germany, and 4.7 million in Australia (The World Bank, 2015). Generally, the main consideration of a migrating decision is economic improvement e.g better job opportunities, bigger plot of land to cultivate, or more amenities which implies higher welfare (Nair, 2001; Meenakshisundaram, K. S. \& Panchanatham, N., 2013; Chi, G. \& Marcouiller, D. W., 2013).

Some literature showed that there are other factors explaining migration aside from economic motives. Some scholars found that people may also choose to migrate due safety reasons. The most intuitive examples will be war or political refugees. For instance, there was a significant increase in the number of refugees from Egypt after the 2011 political unrest following the impeachment of its former president Hosni Mubarak. The number rose from
6,913 people in 2010 to 10,020 people in 2012 (The World Bank, 2015). Recently, there are thousands of refugees left Syria for Turkey to avoid the civil war and the ISIS terror it entails (Salopek, 2015) not to mention the Rohingya ethnics fleeing the allegedly genocide in Myanmar.

Though as not as substantial as war or political unrest, disaster(s) also encourage people to migrate. After the Katrina hit in 2005, there were about 485,318 people moved out from the affected region as refugees. This figure was comprised of 277,682 from Louisiana, approximately 106,000 from Mississippi, and 101,626 from Alabama (The United States Census Bureau, 2015). Safety reason might even range to health issue(s). The malaria, tuberculosis, or HIV/AIDS epidemics might drive people to evacuate an area to move to a safer place (MacPherson, Gushulak, \& Macdonald, 2007).

In the case of Indonesia, the same also applies. For instance, Ananta and Arifin (2014) found that people migrate due to economic reasons such as exploring new job opportunities, 
investments, as well as human capital accumulation. Other scholar suggests that some Indonesians migrate since migration is embedded in their cultural values such as those from Northern and Western Sumatera. It was also found that some people left their place of origin due to political and safety considerations which happened to people in Aceh, Maluku and the former province of East Timor (Muhidin, 2013). On the other hand, Broek (1946) suggested that the many waves of in-migration to The Netherlands Indies took place even way beforehand. It was then argued that migrations actually contributed to the remarkably diverse local cultures of the people even though it is primarily consisted of Malayan stock.

An examination on domestic migration in the context of developing countries is crucial since it can have significant implications on the economic development and social changes within those nations (Olson, 1979 in Hugo, 2006). This study is intended as an information disclosure for factors motivating migration across time in Indonesia. Though economic consideration is believed to be consistently relevant, other aspects might play different roles at different time. Furthermore, this study also aims at providing further explanation on Indonesian migration pattern. Previous studies have shown that more often than not, migration has a historical aspect attached to it. To name a few will be those by Nair (2001) and Hoey (2003). Li, Weslund, and Cars (2010) also contributed to the literature of migration by explaining inter-temporal migration pattern in China and The Great Britain. Adding Indonesia to the list of observed countries will enrich the body of literature even further.

Historically, Indonesia underwent several political transformations which had implications on its economic activities; including the migration pattern. During colonization, all economic activities were controlled and executed by the Dutch with the sole purpose of benefiting the colonial government. Throughout Indonesia's independent era, Suharto was the longest ruling president. Consequently, his economic policies were arguably the ones with the most impact on the country's economic condition. Following his resignation in 1998, Indonesia's economy substantially changed. It shifted from relatively dominated by centralistic administration to a more decentralized and somewhat market oriented government. Given the aforementioned characteristics of Indonesia's economic 146 milestones, the rest of the article will be organized as follows: Section 2 explains Indonesian migration during the Dutch Colonization, section 3 explains Indonesian migration during The Suharto era, section 4 describes the current migration condition, and section 5 concludes.

\section{Indonesian Migration during the Dutch Colonization}

Hugo (2006) suggested that virtually all population mobility in Indonesia during the colonial era was considered forced migration. It is brought by the substantial shift in economic structure designed to accommodate the exploitative colonial aims of concentrating job opportunities. The fundamental colonial system was designed to control the local population and transport the raw materials in the cheapest way possible. It was also complemented by the imposition of the colonial laws which encouraged (or discouraged) some types of migration as well as a various taxation schemes and a range of forced or semi-forced labor schemes. Policies to control labor supply were central to the whole colonial system and it influenced the flow of migration (Hugo, 2006).

In 1830, the Dutch colonial administration started the Cultivation System intended to take the lead in exploitation of Javanese soil and people. Its administrative company (Binnenlands Bestuur) supervised it as a type of forced cultivation of cash crops for European markets. The Cultivation System was implemented primarily to recruit labor at such a low cost so that products produced by them could compete in the world market. It was further claimed that the Cultivation System caused flow of workers which then secured the supply of cheap labor (Bosma, 2007).

The Cultivation System involved remissions on the peasants' land taxes in return for their choice to cultivate the governmentowned cash crops on one-fifth of his land or, alternatively, to work on government's project (ranging from plantations to building roads) for 66 days. Because most lands were used to support the Cultivation System, it later caused shortage of food in the areas and killed around 300,000 people in famine (Day, 1904 in Hugo 2006). A substantial population movement took place after the disaster. People moved away from areas managed by the system to plots of land not managed by it or to plots owned by private individuals. One example will be the Gunung 
Kidul region. Many people migrated to that region since it was not occupied by the Dutch because the land was ill-suited for their cash crops. Consequently, it caused over population in the region (Bailey, 1962 in Hugo, 2006). These studies suggested that the Cultivation System benefited the Dutch more than the natives.

Along with The Cultivation System, it was recorded that between 1905 and 1941 the Dutch administration had conducted four waves of transmigration and transferred more than 180,000 individuals from Java to the outer islands (Table 1). The first wave was smallscaled and experimental which took place between 1905 and 1911. The second stage was better organized and planned which allowed more people to participate. From 1922 - 1931, the number of participants declined as The Dutch administration tried to cut back on its expenses. By 1932 the bawon system was adopted as a substitute for the existing system. It was a traditional Javanese employment scheme in which workers were compensated by a portion of the crop. Under The Dutch, workers were brought in to help existing workers just in time for harvest. They were compensated by accommodations, food, and a part of the harvest (MacAndrews, 1978). The transmigration program was later adopted to be a national program by Indonesian government after its independence.

Table 1. Transmigration Participants during the Dutch Colonial Era

\begin{tabular}{ccc}
\hline Year & Participants (persons) & Phase \\
\hline $1905-1911$ & 6,500 Experimental \\
$1912-1922$ & 16,838 Financed by bank loan \\
$1923-1931$ & 4,000 Financed by bank loan \\
$1932-1941$ & 162,600 The "bawon" system \\
Total & 189,938 \\
\hline
\end{tabular}

Source: McNichol, 1975 in MacAndrews, 1978

Java has long been more densely populated than other parts of the archipelago. At the beginning of the $19^{\text {th }}$ century, it was estimated to have a population of nearly 5 million which then increased to about 25 million in 1895. Java had an average population of 900 people per square mile in contrast of other provinces with the average of 30 . In the 1930 s, population pressure started to reach a critical point which called for actions to reduce it. One of which was through emigration to other islands that need additional labor supply due to their shortage of labor but excess of uncultivated land (Broek, 1946). An example to address the issue was through an effort to cultivate high-quality tobacco in East Coast of Sumatra using Javanese coolies. This has led to a considerable migration which helped reduce the population pressure in Java (Broek, 1946). Other examples will be the cultivation of rubber, tea, palm oil, and sisal which then helped Sumatra to become the new colonial activity and contract coolies system to become more and more established through recruitment of workers for planters (Hugo, 2006). However, neither The Cultivation System nor The Transmigration System can be considered significant compared to Java's continuous population growth (Bloch, 1939).

Migration of Javanese coolies created scattered settlements in Sumatera and then later induced a more general scheme to encourage emigration from Java. The scheme mostly involved a solicitation of larger area of settlements compared to their original communities in Java. Contract coolies system eventually contributed to the fact that many Sumatran populations were Java-Madura born (Volkstelling IV, 1936 in Hugo 2006). The $19^{\text {th }}$ century also marked the rise of manufacturing sectors in Java with the expansion of factories especially in East Java. In this era, the colonial government allowed forced labor to be recruited into factories. Usually, labors would live in designated areas within 5-10 kilometer radius of the factory (Elson, 1986 in Hugo 2006).

The above mentioned studies showed that both the Cultivation System and the Transmigration System practiced in the Dutch colonization era focused more heavily on the population movement; transferring people from Java to the outer islands. The population reduction was also shown to be motivated by the intention of natural resource exploitation through provision of human resources which enabled more cash crops to be produced.

\section{Migration during the "Oppressive" Suharto era}

Efforts to redistribute the population areactually common practices in developing economies. It is also common to do it through government programs such as the two most publicized ones of Brazil and Indonesia (O'Connor, 2004). In Indonesia, transmigration program started in the Dutch colonial era as a small-scale attempt to reduce excess population pressure in Java. Technically, it encouraged people in Java to 
occupy relatively vacant lands such as those in Sumatera and Kalimantan through incentives of securing a plot of land to own and cultivate. Over the years the various types of transmigration gradually categorized mainly by the amount of aid they received from the government. The first type is called the general type where participants were financially supported from the time they left their original place in Java through the initial settlement period. It would end when the village was finally handed over to the appointed leader. The second type was the spontaneous transmigration where migrants voluntarily participate in the program and once they reached the new place can settle on a government project (MacAndrews, 1978).

After Indonesia proclaimed its independence in 1945, transmigration was taken over by the national government and by $1950 \mathrm{~s}$ the program had transported nearly 27,000 people annually through its several stages. Later, it evolved into a massive program that moved thousands of families annually under the administration of Indonesia's second, longest ruling president, Suharto (Table 2). However, the political unrest following the attempted coup in 1965 brought down the number quite considerably (MacAndrews, 1978).

Table 2. Transmigration participants in independent Indonesia

\begin{tabular}{crr}
\hline Year & $\begin{array}{c}\text { Participants } \\
\text { (persons) }\end{array}$ & $\begin{array}{c}\text { Annual Average } \\
\text { (persons) }\end{array}$ \\
\hline $1951-1955$ & 111,595 & 22,319 \\
$1956-1960$ & 134,371 & 26,874 \\
$1961-1965$ & 141,844 & 28,369 \\
$1966-1969$ & 27,712 & 5,542 \\
$1970-1974$ & 182,404 & 36,481 \\
Total & 597,926 & \\
\hline
\end{tabular}

Source: McNichol, 1975 in MacAndrews, 1978

Population redistribution remained an important issue since human resource disparity continued to take place even in $20^{\text {th }}$ century Indonesia. According to MacAndrews (1978) by mid 1970s Java which only made up $6.1 \%$ of Indonesia's total land area was home to more than $60 \%$ of the country's population. Sumatera, which is $24.9 \%$ of Indonesia's total area, housed approximately $17 \%$ of the population. Kalimantan with $28.3 \%$ of Indonesia's area housed around $4.4 \%$ of the population and Sulawesi which was $9.4 \%$ of Indonesia's area hosted around $4 \%$ of the population. The national average was around 60 persons per square kilometer but Java had an average of 565 persons per square kilometer.

Due to the population pressure, land is extremely pricey and land tenure was uncertain in Java. Hence, the chance to secure a land was obviously appealing (Fasbender \& Erbe, 1990 in O'Connor, 2004). Several studies supported and confirmed this statement. It was found that in South and Central Kalimantan, migrants were predominantly those from the poorest households in Java with education achievement being lower than the national average (Karyono, Abdoellah, \& Siswandono, 1980 in O'Connor, 2004). A majority of the migrants were peasants or minor farmers, which explains why land ownership and willingness to migrate were found to be negatively correlated (Dawson, 1994 in O'Connor, 2004). Aside from the effort to reduce population pressure in Java that many literatures seem to have too much emphasis on, transmigration was actually also a way to redistribute human resources for the development of outer islands. The idea was that uncultivated lands can be transformed into productive ones as workers are added. As more agricultural outputs are produced, the society's living standard may also be improved (MacAndrews, 1978).

Government intervention in society's movement can also take a more commanding form. For instance, according to the 1971 census nearly a quarter of the Papuan population was born outside the province. A majority of it was brought by the military concentration aimed at maintaining Papua's integrity as a part of Indonesia (Al Araf, et. al., 2011) and government administration (Upton, 2009) which caused the demographic distribution to shift several years afterwards.

During the Suharto era, voluntary migration also took place across the country. Predominantly, it flows from less developed areas into the more developed ones. Most of the migrations were motivated by intentions to improve life quality through higher income, higher education attainment, and better health care facilities. For instance, Upton (2009) found that the main reasons why people in Papua move to their capital (Jayapura) were to find employment and to gain better education (for themselves and for their children). It was also found that migrants chose Jayapura rather than other cities due to their potential social network 
provided by relatives or friends who have migrated to Jayapura beforehand. This social network was perceived to be instrumental in their transitional period since it would help maintaining a familiar environment. Eventually, this network would prompt a chain migration, i.e. a migration of an individual followed by family member, relatives, or friends (Upton, 2009).

Papua had witnessed up to 780,000 inmigrants coming into the island during 19702000. Around 220,000 were settlers brought by the transmigration program and the remaining 560,000 were spontaneous/voluntary migrants. Most of the voluntary migrants came from South Sulawesi while transmigrants were predominantly Javanese. Before long, migrants quickly outnumbered the locals (Chauvel, 2006). The economically weak Papuan natives were displaced from their own land and deprived from the access to their land. Hence, from the perspective of native Papuans the transmigration program has not been economically beneficial (Rumbiak in Chauvel, 2006).

Despite its long history and the various administrations organizing it, the Indonesian transmigration program had not quite live up to its noble expectation of improving welfare. Many of the migrants ended up in a worse situation after participating in the program usually due to their unfamiliarity with the new area, climate, and conditions which called for a different farming technique. The new plots of lands are usually nutrient-poor; ill-suited for the wet rice cultivation those migrants are accustomed to (O'Connor, 2004). This unanticipated aspect of the transmigration program led to $65 \%$ of migrants in Sumatra to live in poverty; a devastating outcome (Holden, Hvoslef \& Simanjuntak, 1995 in O'Connor, 2004).

The program also failed to accomplish the objective of redistributing population. It was reported that by the $1970 \mathrm{~s}$ the program had moved about 990,000 people to the outer islands, a menial figure compared to the 35 million increase of population in Java. The high rate of in-migration flow from outer islands to Java as well as high fertility rate can be easily argued to be the two main contributors. The goal of living standard improvement through human resources provision in the outer islands was not obtained either. As the transmigration program was taking place, South Sumatera province had already faced a problem of overpopulation. However, the low quality of land and migrants' unfamiliarity with the new farming technique prompts the classic accompanying problems of overpopulation such as unemployment and low income (MacAndrews, 1978).

Furthermore, the fact that migrants remained socially separated from the natives did not help them adjust to their new habitat. This was partly due to the migrants' choice to keep their original Javanese culture and farming technique which, though not intended, created an idea that transmigration was a form of cultural imperialism while in reality it may be because the Javanese way was the only farming technique migrants knew. Their "stubbornness" was actually an attempt to survive in the unknown lands instead of their superiority bias. This false impression later caused resentment from the natives towards migrants and the entailed government facilities, i.e. subsidies they received (Oey, 1981 in O'Connor, 2004). Migration implies competition for plots of land and other resources between local inhabitants and migrants. Migrants also often worked at industrial plantations; viewed as stealing jobs and lands from the natives (O'Connor, 2004).

\section{Migration in Democratic Indonesia}

Muhidin (2013) stated that current day Indonesia is characterized by smaller family sizes, longer life expectancy, and higher education attainment. Concurrently, Indonesia also encounters a significant road and air transportation improvement which facilitate population mobility. In general, there is a shift in the migration pattern and destinations of migrants. Some provinces such as Central Java, East Java, and South Sulawesi that were previously less attractive to migrants became more attractive. In 2000 Central Java's net migration rate was $2.4 \%$. The negative sign means that the outmigration flow was larger than the in-migration flow and the difference was $2.4 \%$ relative to its total population. In the same year, East Java had a net migration rate of $-1.1 \%$ and South Sulawesi had a net migration share of $-1.5 \%$. However, in the year 2010 these provinces had a net migration rate of $0.7 \%, 0.2 \%$, and $1.1 \%$ respectively. Other provinces showed a contrary phenomenon such as those of Jambi, Yogyakarta, and Central Sulawesi. In the year 2000 net migration rate in Jambi was $1.2 \%$ but dropped to $-0.7 \%$ in year 2010. In Yogyakarta, it was 2.3\% in 2000 and $-9.4 \%$ in 2010. In Central Sulawesi, net migration was $2.5 \%$ in 2000 but in 2010 fell to $-6.3 \%$ (Muhidin, 2013). For the specific cases 
of Yogyakarta and Central Sulawesi, they were triggered by both natural and man-made disaster. Many people fled Yogyakarta as a result of Mount Merapi eruption in 2010 while Central Sulawesi refugees were results of the civil conflict that took place in Poso.

Indonesia's migration pattern also shows a change in orientation. Previously, migration was dominated by movement from Indonesia's outer islands into Java (more specifically Jakarta) but now it is predominantly between provinces within an island. For instance, the out-migration from the province of Riau to another Sumatran province was recorded to increase from $50 \%$ in $1985-1990$ to $69 \%$ in $2005-2010$ periods. On the other hand its out migration to places in Java was reported to fall from $44 \%$ to $25 \%$ within the same time frame. Many of the migrants perceived that movement to neighboring or adjacent provinces to be the most feasible (Muhidin, 2013).

This phenomenon suggests that nowadays Indonesians tend to be more thorough when considering their migration decision. While moving to Jakarta might be highly attractive due to its role as the nation's capital and business center, it is also more costly to do for those living in further areas. Further migration also implies higher risks since it is harder to return to their origin if anything should happen in the new place. Wang, Zhou, \& Chang (2013) reported that education level is negatively correlated with risk taking behavior. Along this line, the more educated Indonesians examine the aspect of risks before actually decide to move or not to move.

Indonesia's migration pattern has become more complicated to explain in the post-Suharto era. Some indicators, such as the inter-regional migration, showed high integration level which might suggest higher convergence in labor productivity. Previously, the labor market was geographically segregated. There were provinces with labor productivity more than double the national average while other provinces were less than half the national average. Provinces with higher labor productivity were dominated by formal, modern sectors such as mining and services; while those of lower productivity were dominated by agriculture. But now, education improvements allow poorer provinces to increase their productivity since fewer workers participate in agricultural activities and move to more modern sectors elsewhere. Labor productivity drops in the richer provinces due to migration in- flows while it increases in the poorer regions due to out-migrations.

However, the labor market also seems to become even more fragmented due to the stagnation of manufacturing in Java and the dramatic decentralization which allows returns of revenue to resource-rich provinces (Manning \& Purnagunawan, 2013). Indonesia's manufacturing sectors are characterized by uneducated workers. As the manufacturing sectors stagnate, these workers are trapped in their current places since they are not equipped to relocate to different places and sectors. On the other hand, highly educated workers can maximize their return to education by working in predominantly fast-growing, resource-rich provinces. These phenomena imply more opportunities for human resource development and economic diversification in some regions but not in others. For instance, Kalimantan as one of the richest agricultural island recognizes a high level of employment though witnesses a deindustrialization process due to a decline in its wood-based industries. It remains attractive to workers due to the rise of its oil palm plantations and its coal mining ventures (Manning \& Purnagunawan, 2013).

Despite the change in destination, the factor motivating the movement was shown to be more persistent. Van Lottum and Marks (2011) reported that interprovincial migrations rose from 7\% to around 10\% during 1990-2000 and it was almost always a function of economic consideration. It shows that factors explaining migration flows have not changed much through the years, even compared to colonial days. The sizable attractiveness of Java (especially Jakarta) and wage differentials continue to be the main explanatory variables since they are the most important aspects of a labor market (van Lottum $\&$ Marks, 2011). It was found that main reasons for migration are work and job seeking though not very far behind are education, marriage, housing, and family reunion; a family member (usually the household head) initialized a migration then followed by the remaining members (Muhidin, 2013). It makes the reliance on family links become more important compared to other factors such as government intervention. For instance, even though there was a moratorium on transmigration, the number of population who migrated remained high as they had more members outside their original area they could depend upon (Bacthiar, 2011 in Bachtiar \& Prasetyo, 2014). On the side note, 
this is also true for the case of international migration. Indonesian workers in Malaysia and Brunei brought along their family and friends to the host countries every time they return from a holiday (Bachtiar \& Prasetyo, 2014).

\section{CLOSING REMARKS}

Migration in Indonesia has taken place for centuries. It was recorded that in 1887 there was a massive flow of Indonesian out-migration workers to Malacca (current day Singapore and Malaysia) despite the colonial administration's effort to deter it. The migration flow continued to take place even though The Netherlands Indies (current day Indonesia) government tried to slow it down through passport enforcement and other agreements with the British colonial administration (Gooszen, 1999 in Bachtiar, 2011). On the other hand, Broek (1946) suggested that the many waves of in-migration to The Netherlands Indies took place even way beforehand. It was then argued that migrations actually contributed to the remarkably diverse local cultures of the people even though it is primarily consisted of Malayan stock.

This study aims at disclosing factors explaining Indonesian migration from a historical perspective. It is observed that throughout the centuries migration has beenreported to be almost always a function of economic considerations although it was manifested in different forms. During the colonization era almost all migration was involuntary and was conducted with a sole purpose of benefitting The Dutch. Economic considerations was manifested in the way that it was organized in order to produce cash crops for the Dutch and to supply labors to tend for crops in outer islands. From the Indonesians' perspective, economic considerations took form in an access to vacant land which implies attainment of a productive resource in return for planting the designated cash crops.

The so-called oppressive era of former President Suharto was marked by the massive number of migration either through the nationalized transmigration program or through the military activities. In this era, an economic consideration from the central government perspective was to narrow down the human resource gap between regions in order to boost development in outer islands. From individual perspective, it was manifested in individuals' effort to attain land to cultivate and a chance to generate higher income as well as attaining better education and healthcare facilities. These latter aspects were also the reasons why nationally administered transmigration program seems to fail to serve its purpose of redistributing population.

Manning and Purnagunawan (2013) found that there is a dramatic improvement of telecommunications in current day Indonesia which is characterized by the massive use of cellphones and access to the internet. These improvements and the new society's characteristics of smaller family sizes, longer life expectancy, and higher education attainment had surely contributed to the greater mobility of people, ideas, as well as capital. Indonesia observes a change in migration pattern in such a way that it is difficult to explain. Though it shows convergence due to inter-regional migration and shifts of labor productivity, it also shows divergence at the same time due to the dramatic decentralization that took place since 2001. Migration destinations also shifted from Java oriented to more diversed migration destinations with new growth poles such as Batam and Makassar. In order to support these new growth poles and even create new ones, proper infrastructure provision in the outer islands such as new docks and airports is crucial. Otherwise, people will continue to be drawn to Jakarta due to its extravagant amenities. Consequently, the government's effort to redistribute population through the transmigration program will be meaningless and Jakarta overpopulation pressure will continue to take place.

Additionally, current day Indonesia is characterized by the increasingly common return migration. Return migrants are expected to contribute to the society by bringing new ideas and business skills that will foster modernization as well as lessening brain drain in the origin area (de Haas, 2010; Dustman et.al, 2010 in Bachtiar \& Prasetyo, 2014). However, this expectation is not met in most cases. Upon returning to their mostly rural homes, they succeeded in improving their family livelihood but failed to act as agents of change through implementation of new ideas and modernization. These return migrants were more drawn into consumptive instead of productive purchases such as agricultural machineries (Bachtiar \& Prasetyo, 2014).

Change in mindsets - which is believed to be most effectively achieved through education is required to complement infrastructure improvement. Education attainment, however, 
also promises higher income which is in fact the main reason for schooling. As long as the return to education is low in a particular area, educated individuals are likely to migrate and stay in places where returns to education are higher. They may send significant remittances to their families at home but their contribution to society's improvement is negligible. A carefully designed scheme has to be implemented so that education-motivated migration will not backfire.

One way to do so is through conditional cash transfer in a form of scholarships. For a long time, many international funding agencies as well as foreign educational donors have required grantees to return home upon completion of their study. This is to ensure that acquired skills are maximally utilized for society's development. Indonesian government has provided various types of scholarships. They range from ones offered to high school graduates applying for college such as Bidik Misi, to those allocated for doctoral students such as LPDP scholarship funding. A mandatory service residency will guarantee that human capital investments are exploited for the local economy. Additionally, the government can also prioritize grants for selected fields that are highly required by the nation and/or the region. That way, human capital accumulation is intentionally designed to be relevant for the local economy. An improved skill is essential for the development process since it directly affects productivity. In its absence, better infrastructure will only lead to more frequent chain migration without necessarily enhancing the welfare of the original $\operatorname{area}(\mathrm{s})$.

\section{REFERENCES}

Al Araf, Aliabbas, A., Manto, A., Reza, I. R., Satriya, C., Mabruri, G., ... Indarti, P. (2011). The securitization in Papua: The implication of security approach towards human rights condition in Рариа. Jakarta: IMPARSIAL.

Ananta, A., \& Arifin, E. N. (2014). Emerging patterns of Indonesia's international migration. Malaysian Journal of Economic Studies, 51(1), 29-41.

Bachtiar, P. P. (2011). Migration outflow and remittance patterns in Indonesia: National as well as subnational perspectives. Philippine Journal of Development, 38(1 \& 2), 27.

Bachtiar, P. P., \& Prasetyo, D. D. (2014). Research report: The return migration and various reintegration programs for low skilled migrant workers in Indonesia. Jakarta: The SMERU Research Institute.

Bloch, K. (1939). A new nation arising: Netherlands East Indies, with 70,000,000 population, adjusting themselves to modern world. Barron's (1921-1942), $19,20$.

Bosma, U. (2007). The cultivation system (18301870) and its private entrepreneurs on colonial Java. Journal of Southeast Asian Studies, 38(2), 275-291.

Broek, J. O. (1946). Man and resources in the Netherlands Indies. The Far Eastern Quarterly (pre-1986), 5(2), 120.

Chauvel, R. (2007). West Papua: The flawed integration into Indonesia. In E. E. Hedman (Ed.), RSC Working Paper No. 42: Dynamics of conflict and displacement in Papua, Indonesia (pp. 32-51). Oxford, United Kingdom: Refugee Studies Centre, University of Oxford.

Chi, G., \& Marcouiller, D. W. (2013). Natural amenities and their effects on migration along the urban-rural continuum. The Annals of Regional Science, 50, 861-883.

Hoey, B. A. (2003). Nationalism in Indonesia: Building imagined and intentional communities through transmigration. Ethnology, 42(2), 109.

Hugo, G. (2006). Forced migration in Indonesia: Historical perspectives. Asian and Pacific Migration Journal, 15(1), 53-92.

Li, Y., Westlund, H., \& Cars, G. (2010). Future urban-rural relationship in China: Comparison in a global context. China Agricultural Economic Review, 2(4), 396-411.

MacAndrews, C. (1978). Transmigration in Indonesia: Prospects and problems. Asian Survey, 18(5), 458-472.

MacPherson, D. W., Gushulak, B. D., \& Macdonald, L. (2007). Health and foreign policy: Influences of migration and population mobility. Bulletin of the World Health Organization, 85, 200206.

Manning, C., \& Purnagunawan, R. M. (2014). Regional labour markets in 2002-12: Limited convergence but integration nonetheless. In H. Hill (Ed.), Regional dynamics in a decentralized Indonesia 
(pp. 342-367). Pasir Panjang, Singapore: ISEAS Publishing.

Meenakshisundaram, K. S., \& Panchanatham, N. (2013). Study of agricultural labourers migration social network and the migration behaviour. Indian Journal of Commerce \& Management Studies, 4(3), 32-35.

Muhidin, S. (2014). Migration patterns: People on the move. In H. Hill (Ed.), Regional dynamics in a decentralized Indonesia (pp. 317-341). Pasir Panjang, Singapore: ISEAS Publishing.

Nair, S. (2001). Does migration lead to poverty resolution? A longitudinal analysis of movers versus non-movers. Published $\mathrm{PhD}$ dissertation, Case Western Reserve University - Cleveland, Ohio.

O'Connor, C. M. (2004). Effects of central decision on local livelihoods in Indonesia: Potential synergies between the programs of transmigration and industrial forest conversion. Population and Environment, 25(4), 319-333.

Salopek, P. (2015, March). Perjalanan keluar dari nirwana. National Geographic Indonesia, 11(3), 84-91.
The United States Census Bureau. (2015). Stateto-state migration flows. Retrieved from http://www.census.gov/hhes/migration/d ata/acs/state-to-state.html

Upton, S. (2009). The impact of migration on the people of Papua, Indonesia: A historical demographic analysis. Published $P h D$ thesis, University of New South Wales Sydney.

Van Lottum, J., \& Marks, D. (2012). The determinants of internal migration in a developing country: Quantitative evidence for Indonesia, 1930-2000. Applied Economics, 44, 4485-4494.

Wang, Y., Zhou, W., \& Chang, K. C. (2013). Effect of decision makers' education level on their corporate risk taking. Social Behavior and Personality, 41 (7), 1225-1230.

World Bank. Trends in total migrant stock: 2012 revision. Retrieved from http://data.worldbank.org/indicator/SM.P OP.TOTL 
Jurnal Manajemen Maranatha ø Vol. 16 Nomor 2, Mei (2017) 